\title{
Pendekatan Restorative Justice Dalam Penyelesaian Tindak Pidana Kekerasan Dalam Rumah Tangga
}

\author{
Dheny Wahyudhi, Herry Liyus \\ Fakultas Hukum, Universitas Jambi, Indonesia
}

\begin{abstract}
ABSTRAK
Penelitian ini bertujuan untuk mengetahui bagaimana pendekatan restorative justice dalam penyelesaian tindak pidana kekerasan dalam rumah tangga, pembahasan mengenai kekerasan dalam rumah tangga yang sering terjadi di dalam masyarakat menjadi sebuah permasalahan yang cukup kompleks mengingat kekerasan dalam rumah tangga juga sering terjadi di samping permasalahan kekerasan pada umumnya, penyelesaian terhadap tindak kekerasan dalam lingkup rumah tangga apabila diselesaiakan jalur hukum pidana dirasa kurang tepat, mengingat antara pelaku dan korbannya memiliki hubungan secara personal dan legal, sehingga diperlukan cara-cara penyelesaian yang berbeda dalam menangani konflik dalam rumah tangga tersebut salah satunya dengan pendekatan restorative justice, atas dasar isu hukum tersebut penelitian ini dilakukan. Penelitian ini merupakan penelitian hukum normatif. Selanjutnya dianalisis melalui tahapan interprestasi, penilaian, penelitian, dan evaluasi. Dan terakhir disimpulkan dalam bentuk perskriptif. Dari hasil penelitian diketahui bahwa penyelesaian tindak kekerasan dalam rumah tangga dapat dilakukan dengan pendekatan restorative justice dengan melibatkan korban, pelaku dan pihak yang terkait lainnya yang independen untuk mencari solusi terbaik untuk mencapai kesepakatan dari pada hanya sekedar penjatuhan pidana. Dari kategori tindak kekerasan dalam rumah tangga yang di tentutkan dalam undang-undang tersebut dapat dilakukan dengan pendekatan restorative justice dengan penilaian secara subjektif dan proporsional pada setiap perkara dan tetap memperhatikan kesepakatan antara kedua belah pihak.
\end{abstract}

Kata Kunci: Restorative justice, tindak pidana, kekerasan dalam rumah tangga

\section{PENDAHULUAN}

Di lingkungan masyarakat kita kekerasan yang terjadi dalam rumah tangga menjadi sesuatu hal yang biasa terjadi terhadap pasangan suami isteri bahkan juga tidak jarang terjadi terhadap anak-anak mereka atau bahkan mereka yang tinggal menetap dalam satu rumah seperti kakak beradik, mertua, ipar, pembantu dan lain sebagainya, hal ini tentu merusak tatanan dalam rumah tangga, keharmonisan akan terganggu jika di dalam rumah tangga tersebut terjadi konflik antar anggota keluarga.

Pembahasan mengenai kekerasan dalam rumah tangga yang sering terjadi di dalam masyarakat menjadi sebuah permasalahan yang cukup kompleks mengingat kekerasan dalam rumah tangga juga sering terjadi di samping permasalahan kekerasan pada umumnya, ada yang berbeda antara kejahatan dalam rumah tangga dengan kejahatan pada umumnya yakni terletak pada hubungan antara pelaku dan 
korban yang memiliki kedekatan baik secara personal maupun legal yang dapat berdampak pada kehidupan sosial di dalam masyarakat.

Salah satu yang dilakukan oleh pemerintah dalam rangka memberikan perlindungan terhadap perempuan yakni dengan diratifikasinya konvensi mengenai dihapuskannya segala tindakan diskriminasi yang dilakukan terhadap perempuan Convention on the Elimanition of All Form of Discrimination Agains Women (CEDAW) ${ }^{1}$ yang telah diratifikasi oleh Indonesia melalui Undang-Undang Nomor 7 Tahun 1984. Disadari sepenuhnya bahwa CEDAW sendiri dibentuk berbasis pada falsafah individualistis, suatu falsafah yang menekankan pada penghormatan dan kebebasan setiap individu, sehingga tidak mengherankan jika konsep penelantaran dalam

Undang-Undang Nomor 23 Tahun 2004 tentang Penghapusan Kekerasan Dalam Rumah Tangga (PKDRT) merupakan pelaksanaan amanat materi muatan Undang-Undang PKDRT yang ada sekarang juga berlandaskan pada falsafah tersebut. $^{2}$

Di dalam pengaturan undang-undang kekerasan dalam rumah tangga ini, setidaknya ada empat bentuk kekersan yaitu, kekerasan fisik, psikis, seksual dan penelantaran rumah tangga sebagai bentuk kekerasan ekonomi. ${ }^{3}$ Perbuatan yang termasuk dalam kategori penelantaran rumah tangga yakni seseorang yang menurut hukum yang berlaku wajib memberikan perawatan atau pemeliharaan kepada orang yang menjadi tanggung jawabnya dan juga terhadap orang yang membatasi melakukan pekerjaan di luar rumah yang menyebabkan korban menjadi di bawah kendali orang tersebut. ${ }^{4}$

Penyelesaian terhadap kasus kekerasan dalam rumah tangga masih berpedoman pada hukum acara pidana yang sama dengan perkara pidana pada umumnya, prosesnya diakhiri dengan pemidanaan apabila terdakwa terbukti melakukan tindak pidana sesuai dengan dakwaan penuntut umum. Apabila di dalam undang-undang ini menghendaki keutuhan dan kerukunan rumah tangga maka yang diperlukan adalah prosedur penanganan perkara dengan mediasi penal sebagai bagian dari proses penyelesaian perkara. Sebagaimana yang diatur di dalam undang-undang peradilan pidana anak yakni adanya penyelesaian melalui diversi dengan syarat yang dintentukan dalam undang-undang yang konsekuensinya wajib dilaksanakan.

Kalau kita perhatikan kekerasan yang terjadi dalam lingkup rumah tangga khususnya di Kota Jambi ada kecendrungan peningkatan kasus hal ini dapat dilihat dari data pada Dinas Pemberdayaan Masyarakat, Perempuan dan Perlindungan

\footnotetext{
${ }^{1}$ Dossy Iskandar Prasetyo dan Bernard 1. Tanya, Hukum Etika \& Kekuasaan, Genta Publishing, Yogyakarta, 2011, hlm, 95

${ }^{2}$ Ketut Sudira, Mediasi Penal Perkara Penelantaran Rumah Tangga, UII Pres, Yogyakarta, 2016, hlm. 1

${ }^{3}$ Aroma Elmina Martha, Proses Pembentukan Hukum Kekerasan Terhadap Perempuan di Indonesia dan Malaysia, Aswaja Pressindo, Yogyakarta, 2013, hlm. 54

${ }^{4}$ Ibid
} 
Anak (DPMPPA) Kota Jambi, sepanjang 2018 ada sebanyak 18 kekerasan terhadap perempuan dan anak. 10 Diantaranya kekerasan terhadap anak dan 8 kekerasan terhadap perempuan. Pada tahun 2019 Dinas Pemberdayaan Masyarakat, Perempuan dan Perlindungan Anak Kota Jambi menerima 68 kasus pengaduan, diantaranya yakni 36 kasus KDRT dan 32 kasus lainnya pelecehan seksual terhadap perempuan dan anak. Kabar mengejutkan didapatkan dari Dinas Pemberdayaan Masyarakat Perempuan dan Perlindungan Anak kota Jambi meski baru berada di awal tahun 2020 sudah ada 8 kasus pengaduan dari masyarakat, jumlah kasus ini bisa lebih tinggi dari fakta dilapangan. Sebab tidak semua orang ingin untuk melaporkan bila mengalami kekerasan karena dianggap sebagai aib keluarga.

Penyelesaian terhadap perbuatan tindak kekerasan dalam keluarga atau lingkup rumah tangga apabila diselesaiakan jalur hukum pidana dirasa kurang tepat, mengingat antara pelaku dan korbannya memiliki hubungan yang sangat dekat, sehingga diperlukan cara-cara penyelesaian yang berbeda dalam menangani konflik dalam rumah tangga tersebut. Kalau di dalam hukum perdata kita kenal adanya alternatif penyelesaian sengketa nonlitigasi yang dilakukan di luar pengadilan, ada beberapa pilihan yang dapat dilakukan oleh para pihak dalam menyelesaiakan konflik yakni dengan cara konsultasi, negosiasi, mediasi, konsiliasi dan penilaian ahli.

Dalam perkembangan penyelesaian perkara pidana terhadap kasus-kasus tertentu tidak lagi diselesaikan melalui jalur formal akan tetapi diselesaikan dengan cara melakukan perdamaian antara pihak pelaku dan korban yang dikenal dengan mediasi penal, penyelesaian dengan cara perdamaian atau lebih dikenal dalam masyarakat Indonesia melalui musyawarah mufakat dengan mekanisme lembaga adat, terhadap penyelesaaian perkara pidana dalam sistem peradilan pidana dilakukan melalui diskresi pihak kepolisian. Di samping itu juga penyelesian di luar peradilan juga ditemukan terhadap kasus anak yang penyelesaiannya di luar peradilan melalui mekanisme diversi dengan memperhatikan jenis kejahatan dan bentuk perbuatan yang dilakukan oleh anak dan berdasarkan peraturan perundangundangan yang berlaku.

Hadirnya sebuah pemikiran baru dalam penyelesaian perkara pidana yang terjadi di dalam masyarakat dengan pendekatan yang berbeda dan melibatkan banyak pihak yakni pelaku, korban, dan masyarakat merupakan cara terbaik untuk dapat menyelesaiakan tindak pidana yang memiliki karakter dan ciri khas tersendiri serta dampak yang ditimbulkan tidak terlalu luas bagi kehidupan bermasyarakat salah satunya terhadap kekerasan yang terjadi dilingkup rumah tangga melalui keadilan restorative justice. Dipilihnya model pendekatan restorative justice dalam penanganan perkara yang memiliki karakter dan ciri khas ini dikarnakan penyelesaian sengketa melalui peradilan umum secara konvensional dirasa belum mampu memberikan kepuasan kepada mereka yang mencari keadilan bahkan 
malah memperburuk keadaan. ${ }^{5}$ Di samping itu penelitian yang dilakukan pada saat ini masih ada hubungannya dengan penelitian penulis sebelumnya yakni berkaitan dengan perlindungan hukum. Sehingga dirasa perlu mengakomodasi kepentingan mereka yang berkonflik tidak hanya pelaku akan tetapi juga korban melalui pendekatan restorative justice.

\section{Rumusan Masalah}

Dari uraian latar belakang tersebut maka peneliti membatasi permasalahan yang akan dibahas dalam penelitian ini adalah:

1. Bagaimanakah pendekatan restorative justice dapat diterapkan dalam penyelesaian tindak pidana kekerasan dalam rumah tangga?

2. Apa saja batasan perbuatan kekerasan dalam rumah tangga yang bisa diselesaikan melalui pendekatan restorative justice?

\section{TINJAUAN PUSTAKA}

\section{Prinsip-Prinsip Restorative Justice}

Menurut Barda Nawawi Arief, metode mediasi penal juga dapat diterapkan untuk semua tipe pelaku tindak pidana atau semua tipe tindak pidana. Perbedaan tersebut antara lain adanya pihak ketiga yang menegahi, pihak ketiga tersebut tidak mempunyai kewenangan memutus, pihak ketiga harus bersikap netral, dan berdasarkan kesukarelaan dan iktikad baik para pihak. ${ }^{6}$

Mediasi penal sebagai instrument dari restorative justice dikenal dengan berbagai istilah yang berbeda. Terminologi yang paling awal yang dikenal adalah Victim-Offender Reconciliation Program. Istilah ini jarang dipakai karena banyak pakar menilai penggunaan istilah rekonsiliasi tidak cocok karena terlalu agamis dan tidak menggambarkan proses perdamaian. Istilah yang lebih banyak digunakan selanjutnya adalah Victim-Offender Mediation (Mediasi antara Korban dan Pelaku). Salah seorang pakar mediasi penal di Dunia, Mark Umbreit memakai istilah pendekatan mediasi yang manusiawi (Humanistic Mediation). Adapun istilah mediasi tidak hanya digunakan dalam ranah hukum perdata saja akan tetapi juga digunakan dalam ranah hukum pidana, penggunaan istilah penal mediation dikarnakan mediasi digunakan untuk mendamaikan mereka yang berperkara pidaana kalau di Belanda dikenal dengan strafbemiddeling sedangkan di Perancis istilah ini dikenal dengan de mediation penale. ${ }^{7}$

Menurut Adrianus Meliala, ${ }^{8}$ penggunaan model restoratif dikarnakan sistem peradilan pidana dan pemidanaan yang sekarang berlaku menimbulkan masalah. Dalam sistem kepenjaraan sekarang tujuan pemberian hukuman adalah penjeraan,

\footnotetext{
${ }^{5}$ Teguh Sudarsono, Alternatif Dispute Resolution, Jakarta, 2009, hlm. 3

${ }^{6}$ Fatahillah A. Syukur, Mediasi Perkara KDRT (Teori dan Praktek di Pengadilan Indonesia), Mandar Maju, Bandung, 2011, hlm. 64-65

${ }^{7}$ Ibid., hlm. 66-67

${ }^{8}$ http:// www.hukumonline.com / detail.com / detail.asp?id=9768\&cl= Diakses Tanggal 3 Maret 2020
} 
pembalasan dendam, dan pemberian derita sebagai konsekuensi perbuatannya. Indikator penghukuman diukur dari sejauh mana narapidana (napi) tunduk pada peraturan penjara. Jadi, pendekatannya lebih ke keamanan (security approach). Selain pemenjaraan yang membawa akibat bagi keluarga napi, sistem yang berlaku sekarang dinilai tidak melegakan atau menyembuhkan korban. Apalagi, proses hukumannya memakan waktu lama. Sebaliknya, pada model restorative yang ditekankan adalah resolusi konflik. Pemidanaan restoratif melibatkan korban, keluarga, dan pihak-pihak lain dalam menyelesaikan masalah. Disamping itu, menjadikan pelaku tindak pidana bertanggung jawab untuk memperbaiki kerugian yang ditimbulkannya.

Penggunaan model restorative justice harus dilakukan pada setiap tingkatan peradilan mulai dari kepolisian, kejaksaan, dan pengadilan serta juga lembaga pemasyarakatan. Ada beberapa prinsip dasar restorative justice melalui mediasi dengan memperhatikan beberapa persyaratan misalnya kekerasan dalam rumah tangga atau pelecehan seksual, yaitu:

1. Adanya persetujuan dari korban

2. Penghentian kekerasan

3. Tanggung jawab pelaku

4. Beban kesalahan ada pada pelaku bukan pada korban

5. Baru dapat dilakukan mediasi kalau si korban menyetujuinya. ${ }^{9}$

Keberagaman yang dimiliki Indonesia baik suku, adat istiadatnya, dan bahasa akan tetapi dalam hal penyelesaian sengketa yang terjadi di dalam masyarakat dilakukan dengan cara musyawarah mufakat hal ini hampir sama dengan penyelesaian dengan cara mediasi, hal ini menunjukkan bahwa penggunaan konsep mediasi dalam penanganan perkara sudah lama digunakan di Indonesia tidak hanya dalam perkara privat akan tetapi juga dalam perkara publik, mereka yang berperkara duduk bersama mencari solusi permasalahannya dengan putusan yang dapat diterima oleh semua pihak. ${ }^{10}$

Penggunaan model mediasi dalam penanganan perkara di Indonesia merupakan sesuatu yang mudah dilakukan hal ini dikarnakan antar hubungan masyarakat tidak jarang masih memiliki hubungan kekerabatan. Sesuai dengan adat ketimuran yang sudah mengakar pada masyarakat, sehingga mereka lebih mengutamakan terjalinnya hubungan silaturahmi yang erat antar keluarga dan masyarakat dari pada mengambil keuntungan pada saat terjadi konflik. Penyelesaian melalui lembaga peradilan tidak menghasilkan sebuah keuntungan bagi mereka yang berkonflik akan tetapi malah sebaliknya hubungan baik menjadi rusak hanya sekedar menyelamatkan nama baik. ${ }^{11}$

${ }^{9}$ http://infokorupsi.com/id/opinion.php?ac=304\&l=keadilan-restoratif, Diakses Tanggal 3 Maret 2020

${ }^{10}$ DS. Dewi, dan Fatahillah A. Syukur, Mediasi Penal: Penerapan Restorative Justice di Pengadilan Anak Indonesiat, hlm. 70.

${ }^{11}$ Ibid, hlm. 71. 
Menurut pendapat Barda Nawawi bahwa penggunaan mediasi penal dimungkinkan dalam kasus tindak pidana anak, tindak pidana orang dewasa (ada yang dibatasi untuk delik yang diancam pidana penjara maksimum tertentu), tindak pidana dengan kekerasan (violent crime), tindak pidana kekerasan dalam rumah tangga (domestic violence), dan kasus perbankan yang beraspek hukum pidana. ${ }^{12}$ Belum adanya landasan hukum yang kuat dalam menyelesaikan perkara pidana diluar pengadilan menjadi masalah tersendiri dalam penerapannya akan tetapi dalam prakteknya hal ini terjadi terhadap perkara tertentu yang tidak dilanjutkan prosesnya ketahap penuntutan di pengadilan melalui diskresi aparat kepolisian.

\section{Pengaturan Kekerasan Dalam Rumah Tangga}

Di dalam undang-undang penghapusan kekerasan dalam rumah tangga tidak hanya mengatur tentang perlindungan dan pemulihan terhadap korban kekerasan dalam lingkup rumah tangga akan tetapi juga mengatur tentang pencegahan. Di samping itu di dalam undang-undang ini juga disebutkan secara spesifik mengenai batasan dan unsur perbuatan hal ini tentu berbeda dengan perbuatan penganiayaan seperti yang diatur dalam KUHP (Kitab Undang-Undang Hukum Pidana). Di samping itu, juga disebutkan adanya kewajiban bagi setiap aparat penegak hukum, tenaga kesehatan, pekerja sosial, relawan pendamping, atau pembimbing rohani untuk memberikan perlindungan terhadap korban sehingga mereka lebih sensitif dan responsif terhadap kepentingan rumah tangga yang sejak awal diarahkan pada keutuhan dan kerukunan rumah tangga.

Lingkup rumah tangga sebagaimana yang disebutkan dalam peraturan perundang-undangan terdiri dari pasanngan suami isteri, anak, dan orang-orang yang mempunyai hubungan keluarga karena hubungan darah, perkawinan, persusuan, pengasuhan, dan perwalian, yang menetap dalam rumah tangga; dan/atau orang yang bekerja membantu rumah tangga dan menetap dalam rumah tangga tersebut dalam jangka waktu selama berada dalam rumah tangga yang bersangkutan. ${ }^{13}$ Adapun tujuan diadakannya perlindungan hukum dalam lingkup rumah tangga adalah: menghindari terjadinya segala ragam kekerasan dalam rumah tangga, melindungi korban terhadap kekerasan yang dialami, mengambil tindakan tegas terhadap pelaku kekerasan dalam rumah tangga dan memelihara keutuhan rumah tangga yang harmonis dan sejahtera. ${ }^{14}$

Di dalam peraturan perundang-undangan ditentukan perbuatan yang dilarang untuk dilakukan yakni:

1. Kekerasan fisik;

\footnotetext{
${ }^{12}$ Barda Nawawi Arief, Barda Nawawi Arief, Kebijakan Legislatif dalam Penanggulangan Kejahatan dengan Pidana Penjara, BP UNDIP. Semarang, cetakan ke-3, 2000, hlm. 169-171

${ }^{13}$ Lihat Ketentuan Pasal 2 Ayat (1) dan (2) Undang-Undang Nomor 23 Tahun 2004 Tentang Penghapusan Kekerasan Dalam Rumah Tangga

${ }^{14}$ Lihat ketentuan Pasal 4 Undang-Undang Nomor 23 Tahun 2004 Tentang Penghapusan Kekerasan Dalam Rumah Tangga
} 
2. Psikis;

3. Kekerasan seksual; atau

4. Penelantaran rumah tangga. ${ }^{15}$

Dalam hal pencegahan terhadap tindak kekerasan dalam rumah tangga dilakukan melalui lembaga kementerian pemberdayaan perempuan yang diberikan tanggung jawab untuk penyelengaraan komunikasi, edukasi, dan informasi dalam lingkup rumah tangga dalam rangka upaya pencegahan terjadinya tindak kekerasan dalam rumah tangga. Sehingga perlindungan hukum juga harus diberikan secara menyeluruh dan memperhatikan korban, pentingnya sosialisasi terhadap masyarakat dalam rangka edukasi dan penyadaran akan pentingnya perlindungan hukum mengingat segala tindak kekerasan yang terjadi dalam rumah tangga merupakan kejahatan terhadap martabat manusia.

\section{METODE PENELITIAN}

\section{Tipe penelitian}

Penelitian yang digunakan yakni penelitian yuridis normatif. Penelitian hukum normatif adalah penelitian kepustakaan yang meneliti bahan hukum atau data sekunder dan data primer dengan mempelajari sumber-sumber atau bahan tertulis dengan menafsirkan dan membandingkan berbagai sumber yang berhubungan dengan penyelesaian tindak pidana kekerasan dalam rumah tangga dengan pendekatan restorative justice.

\section{Pendekatan penelitian}

Setidaknya ada lima pendekatan penelitian hukum yang dikemukakan oleh Peter Mahmud marzuki, yang pertama pendekatan undang-undang (statute approach), yang kedua pendekatan kasus (case law approach), yang ketiga pendekatan historis (historical approach), yang keempat pendekatan perbandingan (comparative approach), dan yang kelima pendekatan konseptual (conceptual approach). ${ }^{16}$ Dalam penelitian ini pendekatan yang peneliti gunakan adalah pendekatan undang-undang dan pendekatan konsep.

\section{Pengumpulan bahan hukum.}

Penelitian ini merupakan penelitian yuridis normatif, maka penelitian ini lebih difokuskan pada penelitian kepustakaan untuk mengkaji bahan-bahan hukum relevan dengan objek penelitian ini dengan menggunakan system kartu (card system).

\footnotetext{
${ }^{15}$ Lihat ketentuan Pasal 5 Undang-Undang Nomor 23 Tahun 2004 Tentang Penghapusan Kekerasan Dalam Rumah Tangga

${ }^{16}$ Peter Mahmud Marzuki, Penelitian Hukum, Kencana, Jakarta, 2008, hlm. 93
} 


\section{Analisis Data}

Data yang diperoleh dianalisis secara kualitatif yaitu data yang tersedia data primer maupun data sekunder yang sudah dikumpulkan. Selanjutnya terhadap hasil tersebut disajikan dalam bentuk deskriptif menggambarkan mengenai pendekatan restorative justice dalam penyelesaian tindak pidana kekerasan dalam rumah tangga. Selanjutnya dianalisis melalui tahapan interprestasi, penilaian, penelitian, dan evaluasi. Dan terakhir disimpulkan dalam bentuk perskriptif.

\section{PEMBAHASAN}

\section{Pendekatan Restorative Justice Dalam Penyelesaian Tindak Pidana Kekerasan Dalam Rumah Tangga}

Pembaharuan hukum pidana dewasa ini tidak lagi menggunakan pendekatan retributive melainkan berkembang kearah restorative dimana kita ketahui bahwa penyelesaian perkara pidana melalui jalur legal formal dirasa belum memberikan pengaruh yang signifikan terhadap menurunnya jumlah kejahatan yang terjadi di dalam masyarakat, masih banyaknya tindak pidana yang terjadi di dalam masyarakat yang ditangani melalui jalur legal formal membawa dampak yang sangat luas tidak hanya menyebabkan terjadinya over kapasitaas di lembaga pemasyarakatan akan tetapi juga berdampak kepada keuangan negara, tidak bisa dipungkiri bahwa terjadinya over kapasitas di lembaga pemasyarakatan tersebut membutuhkan biaya yang tidak sedikit. Sehingga diperlukan cara lain dalam menyikapi tindak pidana yang terjadi, penanggulangan kejahatan tidak hanya dapat dilakukan dengan cara penal saja akan tetapi juga dapat dilakukan dengan upaya non penal, tidak hanya dengan tindakan represif tetapi juga tindakan preventif dalam menanggulangi kejahatan.

Penyelesaian perkara pidana melalui jalur legal formal tidak selamanya membawa dampak yang positif terhadap penegakan hukum, tidak jarang kita jumpai bahwa penegakan hukum pidana yang seharusnya memberikan keadilan bagi masyarakat/yang mencari keadilan malah yang dijumpai adalah ketidak adilan. Permasalahan yang cukup kompleks tersebut dipengaruhi oleh banyak faktor disamping faktor ekonomi akan tetapi juga foktor social dan budaya.

Orientasi sistem peradilan pidana terfokus pada tindak pidana (crime, straafbaarfeit) dan pelaku tindak pidana (criminal, dader). Mindset dari masingmasing komponen sistem peradilan pidana cenderung berpatokan pada aturan formal atau bersifat positivistik tanpa mau mempedulikan kemanfaatan dan rasa keadilan yang merupakan roh dari penegakan hukum pidana. Proses peradilan pidana lebih mencerminkan keadilan antara kepentingan negara melawan kepentingan pelaku. Dengan alasan legalitas, masing-masing komponen sistem peradilan pidana tidak mau mengambil resiko, sehingga penanganan perkara tersebut telah mencederai rasa keadilan masyarakat. Budiman Tanuredja, 
sebagaimana dikutip oleh Syamsul Fatoni bahkan menggambarkan betapa manusia yang lemah berhadapan dengan praktek penegakan hukum yang sekadar mencari kebenaran formal, bukan kebenaran substansial, dimana penegak hukum sangat fasih berbicara soal pasal dan punya sifat memanfaatkan mereka yang lemah. ${ }^{17}$

Menurut Barda Nawawi Arif, efektifitas hukum pidana dapat dilihat dari dua aspek pokok tujuan dari pemidanaan, yaitu aspek perlindungan masyarakat dan aspek perbaikan perilaku dari si pelaku yang dimaksud dengan aspek perlindungan masyarakat meliputi tujuan dari mencegah, mengurangi atau mengendalikan tindak pidana dan memulihkan keseimbangan masyarakat (antara lain menyelesaikan konflik, mendatangkan rasa aman, memperbaiki kerugian atau kerusakan, menghilangkan noda-noda, memperkuat kembali nilai-nilai yang hidup di dalam masyarakat). Aspek perbaikan si pelaku meliputi berbagai tujuan, antara lain melakukan rehabilitasi dan memasyarakatkan kembali si pelaku dan melindunginya dari perlakuan sewenang-wenang di luar hukum. ${ }^{18}$

Adanya pendekatan yang berbeda terhadap penyelesaian tindak pidana menunjukkan bahwa telah terjadi pergeseran di dalam menyelesaiakan permasalahan hukum khususnya hukum pidana yang berkembang mengikuti perkembangan masyarakat itu sendiri secara dinamis, perkembangan yang terjadi tersebut dapat dilihat dari beberapa aspek yakni kebijakan sosial, kebijakan criminal dan kebijakan penegakan hukum itu sendiri, yang orientasinya sesuai dengan nilainilai yang hidup bertumbuh serta berkembang di dalam masyarakat itu sendiri.

Pada prinsipnya, restorative justice dapat digunakan pada setiap tahap sistem peradilan pidana dan akan dapat terlaksana dengan baik, apabila memenuhi syaratsyarat yaitu; pertama, pelaku harus mengaku atau menyatakan bersalah; kedua, pihak korban harus setuju bahwa tindak pidana diselesaikan di luar sistem peradilan pidana; ketiga, kepolisian atau kejaksaan sebagai institusi yang memiliki kewenangan diskresi harus menyetujui pelaksanaan restorative justice; dan keempat, pelaksanaan penyelesaian di luar sistem peradilan pidana harus didukung oleh komunitas setempat ${ }^{19}$

Konsep dasar dari restorative justice ini adalah musyawarah mufakat dalam menyelesaikan permasalahan hukum yang dialami oleh para pihak akibat terjadinya suatu tindak pidana, dimana para pihak menyadari sepenuhnya dan secara sukarela menyelesaikan permasalahan hukumnya melalui musyawarah mufakat tersebut. Artinya baik korban dan keluarganya maupun pelaku dan keluarganya atau pihak

\footnotetext{
${ }^{17}$ Fatoni, S. Pembaharuan Sistem Pemidanaan, Perspektif Teoriti dan Pragmatis untuk Keadilan, Setara Press, Malang, 2016, hlm. 2.

${ }^{18}$ Barda Nawawi Arif. Dalam Dwidja Priyatno, Sistem Pelaksanaan Pidana Penjara di Indonesia, Refika Aditama, Bandung, 2006, hlm. 82.

${ }^{19}$ I Made Tambir, Pendekatan Restorative Justice Dalam Penyelesaian Tindak Pidana Di Tingkat Penyidikan, Jurnal Magister Ilmu Hukum Udayana, 8 (4) DOI: 10.24843/JMHU.2019.v08.i04.p09 Vol. 8 No. 4 Desember 2019, 549-574, hlm. 557
} 
ketiga yang independen dipercaya oleh masing-masing pihak untuk duduk bersama-sama menyelesaikan permasalahan hukum yang dihadapi.

Hal ini juga senada juga diungkapkan oleh John Braithwaite, yang menyatakan bahwa tujuan utama restorative justice adalah perbaikan luka yang diakibatkan oleh perbuatan pelaku dan konsiliasi serta rekonsiliasi di kalangan korban, pelaku dan masyarakat. ${ }^{20}$ Cara-cara seperti itu akan melahirkan perasaan malu dan pertanggungjawaban personal serta keluarga atas perbuatan salah mereka untuk diperbaiki secara memadai ${ }^{21}$

Pendekatan restorative justice dalam penyelesaian perkara tindak kekerasan dalam rumah tangga memberikan peluang yang luas kepada masing-masing pihak yang berperkara untuk berperan secara aktif dalam menyelesaikan perkaranya dengan kesempatan yang proporsional kalau bagi korban tindak kekerasan dalam rumah tangga dapat mengutarakan keinginan dan tuntutannya kepada si pelaku yang selama ini posisi korban dalam tindak pidana diwakili oleh jaksa penuntut umum seringkali apa yang diinginkan korban tidak diakomodir dengan baik dan lebih cendrung hanya melengkapi keterangan saja atau sebagai saksi suatu tindak pidana sementara itu bagi si pelaku dapat menyampaikan pendapatnya secara bertanggungjawab dengan penuh kesadaran menyadari dan menyesali perbuatannya dan bersedia mengganti kerugian yang ditimbulkan akibat perbuatan pidana yang telah dilakukannya.

Dalam mendukung terlaksananya penerapan restorative justice dan adanya kepastian hukum bagi mereka yang mencari keadilan serta menjadi pedoman bagi aparat penegak hukum terutama pada tingkat penyidikan Kapolri telah menerbitkan Surat Edaran Kapolri Nomor 8 Tahun 2018 tentang Penerapan Keadilan Restoratif dalam penyelesaian prkara pidana dan Peraturan Kapolri Nomor 6 Tahun 2019 tentang Penyidikan Tindak Pidana. Selanjutnya pada Penuntutan dalam mendukung pelaksanaan keadilan restorative justice telah diterbitkan Peraturan Kejaksaan Nomor 15 Tahun 2020 tentang Penghentian Penuntutan Berdasarkan Restorative Justice.

Pemberian posisi yang seimbang terhadap masing-masing pihak dengan memberian kesempatan yang sama dengan melibatkan pihak keluarga korban dan keluarga pelaku serta pihak lainnya yang dipercaya membuka peluang untuk diselesaikan dengan cara musyawarah mencari solusi terbaik terhadap perkara yang dihadapi. Dengan mengakomodir pendapat dan keinginan masing-masing pihak bertujuan untuk memulihkan keadaan sehingga konflik yang terjadi dianggap tidak pernah ada dan pemulihan keadaan dapat tercapai melalui pendekatan restorative justice.

\footnotetext{
${ }^{20}$ John Braithwaite, Restorative Justice: Assessing an Immodest Theory and a Pessimistic Theory Draft to be summited to Crime and Justice: Review of Research, University of Chicago, Press, hlm. 5

${ }^{21}$ Nur Rochaeti, Impelementasi Keadilan Restoratif dan Pluralisme Hukum dalam Sistem Peradilan Pidana Anak di Indonesia. Masalah-Masalah Hukum, 44 (2), 150-160. DOI: 10.14710/mmh.44.2.2015.150-160, 2015, hlm. 153.
} 


\section{Tindak Pidana Kekerasan Dalam Rumah Tangga Yang Dapat Diselesaikan Melalui Pendekatan Restorative Justice}

Makna kekerasan secara konvensional adalah apabila manusia dipengaruhi sedemikian rupa sehingga reealisasi jasmani dan mental-psikologis aktualnya berada di bawah realisasi potensialnya. ${ }^{22} \mathrm{Hal}$ ini bermakna bahwa kekerasan yang dialami oleh perempuan realitas jasmani dan mental psikologis daya aktualitasnya tidak mampu merespon lingkungan. Aktualitas dirinya tergedradasi, sehingga harga diri jatuh dan keadaan jiwa yang tertekan. Dalam konteks sosiologis kekerasan terhadap perempuan dapat terjadi dari proses interaksi antara laki-laki dan perempuan yang menghasilkan posisi tawar yang tidak seimbang dalam status peran atau kedudukan, sehingga realisasi jasmani dan psikologis aktualnya berada di bawah realisasi potensialnya. ${ }^{23}$

Secara umum di dalam Kitab Undang-Undang Hukum Pidana telah diatur mengenai penganiayaan dan kesusilaan serta penelantaran orang yang perlu diberikan nafkah dan kehidupan. Secara legal formal pengaturan kekerasan terhadap perempuan khususnya dalam lingkup rumah tangga diatur di dalam Undang-Undang Nomor 23 Tahun 2004 tentang Penghapusan Kekerasan Dalam Rumah Tangga (PKDRT). Di dalam undang-undang kekerasan dalam rumah tangga pembagian deliknya tidak hanya masuk kedalam delik aduan akan tetapi ada juga yang termasuk kategori delik aduan, Kekerasan yang terjadi terhadap perempuan dalam lingkup rumah tangga dapat berupa kekerasan fisik, kekerasan seksual, kekerasan psikis, dan juga kekerasan ekonomi.

Di dalam Undang-Undang Nomor 23 Tahun 2004 tentang Penghapusan Kekerasan Dalam Rumah Tangga (PKDRT) dijelaskan makna dari kekerasan dalam lingkup rumah tangga yang tercantung di dalam Pasal 1 angka 1 yakni: Kekerasan dalam Rumah Tangga adalah setiap perbuatan terhadap seseorang terutama perempuan, yang berakibat timbulnya kesengsaraan atau penderitaan secara fisik, seksual, psikologis, dan/atau penelantaran rumah tangga termasuk ancaman untuk melakukan perbuatan, pemaksaan, atau perampasan kemerdekaan secara melawan hukum dalam lingkup rumah tangga.

Di dalam Kitab Undang-Undang Hukum Pidana dalam Pasal 89 yang dimaksud dengan kekersan yakni menggunakan tenaga atau kekuatan jasmani tidak kecil dan tidak sah, misalnya memukul dengan tangan atau dengan segala macam senjata, menyepak, menendang, dan sebagainya, yang dimaksud dengan "melakukan kekerasan" ialah membuat orang jadi pingsan atau tidak berdaya lagi $(\text { lemah) })^{24}$.

\footnotetext{
${ }^{22}$ Windhu, Kekuasaan dan Kekerasan Menurut Galtung, Kanisius Yogyakarta, 1992, hlm. 64

${ }^{23}$ Munandar Sulaeman dan Siti Homzah, Kekerasan Terhadap Perempuan (Tinjauan Dalam Berbagai Ilmu dan Kasus Kekerasan), Edisi Revisi, PT Refika Aditama, Bandung, 2019, hlm. 44

${ }^{24}$ R. Soesilo, Kitab Undang-Undang Hukum Pidana (KUHP) Serta Komentar-Komentarnya Lengkap Pasal Demi Pasal, Politeia, Bogor, 1998
} 
Kekerasan dalam lingkup rumah tangga, sebagaimana diatur dalam UndangUndang Nomor 23 Tahun 2004 tentang Penghapusan Kekerasan Dalam Rumah Tangga Kekerasan terdiri dari : (a). kekerasan fisik; (b). kekerasan psikis; (c). kekerasan seksual; atau (d). penelantaran rumah tangga. (Pasal 5 UU PKDRT).

Di dalam ketentuan Pasal 6 Undang-Undang Nomor 23 Tahun 2004 tentang Penghapusan Kekerasan Dalam Rumah Tangga Kekerasan yang dimaksud dengan kekerasan fisik adalah perbuatan yang mengakibatkan rasa sakit, jatuh sakit, atau luka berat. Selanjutnya yang dimaksud dengan Kekerasan psikis adalah perbuatan yang mengakibatkan ketakutan, hilangnya rasa percaya diri, hilangnya kemampuan untuk bertindak, rasa tidak berdaya, dan/atau penderitaan psikis berat pada seseorang. (Pasal 7 UUPKDRT). Selanjutnya yang dimaksud dengan Kekerasan seksual meliputi: a. pemaksaan hubungan seksual yang dilakukan terhadap orang yang menetap dalam lingkup rumah tangga tersebut; b. pemaksaan hubungan seksual terhadap salah seorang dalam lingkup rumah tangganya dengan orang lain untuk tujuan komersial dan/atau tujuan tertentu. (Pasal 8 UUPKDRT), dalam penjelasan pasal tersebut yang dimaksud "kekerasan seksual" dalam ketentuan ini adalah setiap perbuatan yang berupa pemaksaan hubungan seksual, pemaksaan hubungan seksual dengan cara tidak wajar dan/atau tidak disukai, pemaksaan hubungan seksual dengan orang lain untuk tujuan komersial dan/atau tujuan tertentu, dan dalam ketentuan Pasal 9 ayat (1) (UUPKDRT) Setiap orang dilarang menelantarkan orang dalam lingkup rumah tangganya, padahal menurut hukum yang berlaku baginya atau karena persetujuan atau perjanjian ia wajib memberikan kehidupan, perawatan, atau pemeliharaan kepada orang tersebut. (2) Penelantaran sebagaimana dimaksud ayat (1) juga berlaku bagi setiap orang yang mengakibatkan ketergantungan ekonomi dengan cara membatasi dan/atau melarang untuk bekerja yang layak di dalam atau di luar rumah sehingga korban berada di bawah kendali orang tersebut.

Pendekatan restorative justice adalah sebuah pendekatan yang berkembang dalam system peradilan pidana pada akhir-akhir ini restorative justice ini juga dikenal sebagai penyelesaian secara kekeluargaan yang melibatkan korban, pelaku dan pihak terkait lainnya untuk secara bersama-sama dengan penuh kesadaran dan bertanggungjawab mencari solusi terbaik dalam menyelesaiakan perkara yang dihadapi, penggunaan pendekatan restorative justice dalam penyelesaian tindak pidana kekerasan dalam rumah tangga dikarnakan penggunaan sarana hukum pidana selama ini masih menimbulkan permasalahan sehingga upaya penal lebih tepat ditempatkan sebagai upaya terakhir atau ultimum remidium, dalam penyelesaian tindak pidana kekerasan dalam rumah tangga.

Dari beberapa kategori tindak kekerasan dalam rumah tangga yang ditentukan di dalam undang-undang yakni: kekerasan fisik, kekerasan psikis, kekerasan seksual dan penelantaran rumah tangga pada dasarnya dapat dilakukan penyelesaiannya dengan pendekatan restorative justice, dikarnakan pada tindak 
kekerasan dalam rumah tangga memiliki karakter dan ciri khas tersendiri yang mana antara pelaku dan korban adalah mereka yang memiliki hubungan yang erat baik secara legal maupun secara personal, penyelesaian tindak pidana kekerasan dalam rumah tangga dengan pendekatan restorative justice akan berhasil dilakukan apabila antara para pihak baik korban ataupun pelaku menyadari sepenuhunya tanpa ada paksaan untuk menyelesaikan masalah hukum yang mereka hadapi dengan duduk bersama mencari solusi terbaik sehingga restorasi dapat dilakukan. Namun apabila salah satu pihak baik korban maupun pelaku tidak mau menyelesaiakan permasalahan hukum yang mereka hadapi secara musyarawarah maka pendekatan restorative justice tidak dapat dilaksanakan dan proses hukum tetap dilanjutkan.

Dilihat dari penyelesian perkara kekerasan dalam rumah tangga dengan pendekatan restorative justice setidaknya ada beberapa syarat yang harus dipenuhi yakni:

1. Dampak dari tindak pidana yang dilakukan tidak terlalu luas

2. Pelaku dengan penuh kesadaran mengakui perbuatannya

3. Korban memafkan kesalahan pelaku

2. Setiap pihak yang terlibat mendukung proses tersebut

Dengan adanya Surat Edaran Kapolri Nomor 8 Tahun 2018 tentang Penerapan Keadilan Restoratif dalam penyelesaian perkara pidana dan Peraturan Kapolri Nomor 6 Tahun 2019 tentang Penyidikan Tindak Pidana serata adanya Peraturan Kejaksaan Nomor 15 Tahun 2020 tentang Penghentian Penuntutan Berdasarkan Restorative Justice menjadi landasan hukum bagi aparat penegak hukum pada tingkat penyidikan dan penuntutan dalam menyelesaiakan setiap perkara khususnya perkara tindak kekerasan dalam rumah tangga dengan pendekatan restorative justice yang lebih mengutamakan pemulihan keaadaan dari pada hanya sekedar penghukuman terhadap pelaku tindak kekerasan dalam rumah tangga dengan demikian keadilan, kemanfaatan dan kepastian hukum dapat diwujudkan dalam setiap penyelesaian perkara tindak kekerasan dalam rumah tangga.

\section{KESIMPULAN DAN SARAN}

Penyelesaian perkara tindak kekerasan dalam rumah tangga dapat dilakukan dengan pendekatan restorative justice dengan melibatkan semua pihak yang terkait baik pihak korban, pelaku atau pihak lainnya yang dipercaya untuk mencari solusi terbaik dalam menyelesaikaan perkara dengan merestorasi keadaan sehingga perbuatan tindak kekerasan dalam rumah tangga tersebut dianggap tidak pernah ada. Kategori tindak kekerasan dalam rumah tangga yakni kekerasan fisik, kekerasan psikis, kekerasan seksual dan penelantaran rumah tangga dapat diselesaikan dengan pendekatan restorative justice dengan penilaian secara subjektif 
proporsional pada setiap perkara dengan memperhatikan kesepakatan kedua belah pihak. Perlunya adanya pemahaman bersama bagi aparat penegak hukum dalam mewujudkan terlaksananya penyelesaian perkara pidana dengan pendekatan restorative justice

\section{DAFTAR PUSTAKA}

Adi Sulistyono, 2006, Mengembangkan Paradigma Non-Litigasi di Indonesia, Surakarta, UNS Press.

Aroma Elmina Martha, 2013, Proses Pembentukan Hukum Kekerasan Terhadap Perempuan di Indonesia dan Malaysia, Aswaja Pressindo, Yogyakarta.

Barda Nawawi Arief, 2000, Kebijakan Legislatif dalam Penanggulangan Kejahatan dengan Pidana Penjara, BP UNDIP. Semarang, cetakan ke-3

Dossy Iskandar Prasetyo dan Bernard, 2011, 1. Tanya, Hukum Etika E Kekuasaan, Genta Publishing, Yogyakarta

DS. Dewi, dan Fatahillah A. Syukur, Mediasi Penal: Penerapan Restorative Justice di Pengadilan Anak Indonesiat

Fatahillah A. Syukur, 2011, Mediasi Perkara KDRT, (Teori dan Praktek Di Pengadilan Indonesia) Mandar Maju, Bandung

Fatoni, S. Pembaharuan Sistem Pemidanaan, Perspektif Teoriti dan Pragmatis untuk Keadilan, Setara Press, Malang, 2016, hlm. 2.

JE Sahetapy, 1987, Viktimologi Sebagai Bunga Rampai, Pustaka Sinar Harapan, Jakarta

John Braithwaite, Restorative Justice: Assessing an Immodest Theory and a Pessimistic Theory Draft to be summited to Crime and Justice: Review of Research, University of Chicago, Press

Ketut Sudira, 2016, Mediasi Penal Perkara Penelantaran Rumah Tangga, UII Pres, Yogyakarta

Munandar Sulaeman dan Siti Homzah, 2019, Kekerasan Terhadap Perempuan (Tinjauan Dalam Berbagai Ilmu dan Kasus Kekerasan), Edisi Revisi, PT Refika Aditama, Bandung

Teguh Sudarsono, 2009, Alternatif Dispute Resolution, Jakarta

Peter Mahmud Marzuki, 2008, Penelitian Hukum, Kencana, Jakarta

Rochaeti, N, Impelementasi Keadilan Restoratif dan Pluralisme Hukum dalam Sistem Peradilan Pidana Anak di Indonesia. Masalah-Masalah Hukum, 44 (2), 150-160. DOI: 10.14710/mmh.44.2.2015.150-160, 2015

Winddhu, 1992, Kekuasaan dan Kekerasan Menurut Galtung, Kanisius Yogyakarta

Undang-Undang Nomor 23 Tahun 2004 Tentang Penghapusan Kekerasan Dalam Rumah Tangga

Undang-Undang Nomor 8 Tahun 1981 tentang Kitab Undang-Undang Hukum Acara Pidana 
Peraturan Pemerintah Nomor 4 Tahun 2006 Tentang Penyelenggaraan dan Kerjasama Pemulihan Korban Kekerasan Dalam Rumah Tangga

Perkap Nomor 6 Tahun 2019 Tentang Penyidikan Tindak Pidana

Peraturan Kejaksaan Nomor 15 Tahun 2020 Tentang Penghentian Penuntutan Berdasarkan Keadilan Restoratif

http:// www.hukumonline.com / detail.com / detail.asp?id=9768\&cl= http://infokorupsi.com/id/opinion.php?ac=304El=keadilan-restoratif, 